\title{
Performance Investigation of Low-Speed Wind Tunnel: Stability Wind Speed in Test Section
}

\author{
F A Alfahma ${ }^{1}$, Erwin $^{1}$, Slamet Wiyono ${ }^{1 *}$ \\ ${ }^{I}$ Mechanical Engineering Department Universitas Sultan Ageng Tirtayasa Jendral Sudirman Street Km. 3, Cilegon, \\ Banten \\ "Corresponding author. Email: maswie@ untirta.ac.id
}

\begin{abstract}
The wind tunnel is a piece of tube-structured test equipment that is forced to go fast, which is used to study the effects of aerodynamic flow on an object [1], as well as aerodynamics has a significant role in the design of a body, fins, turbines and other objects that rub directly against each other, with air or other gases. In this research, a wind tunnel is designed with a section measuring $0.5 \mathrm{~m} \times 0.5 \mathrm{~m}$ which will be used to test direct friction modelling with the Renewable Energy Engineering Laboratory. The wind tunnel has several important parts to produce stable and laminar air in the test section, Honeycombs, Contraction, Test Section, Diffuser and Fan [2]. Determining the size of the wind is done by analytical methods to determine the power of the fan driving motor [3]. This wind tunnel uses a fan with a propeller diameter of $68 \mathrm{~cm}$ and uses a 400Watt electric motor drive. This wind tunnel has a maximum wind speed of $5.5 \mathrm{~m} / \mathrm{s}$ in the test section, and has been tested at speeds of $0.5 \mathrm{~m} / \mathrm{s}, 1 \mathrm{~m} / \mathrm{s}, 1.5 \mathrm{~m} / \mathrm{s}, 2 \mathrm{~m} / \mathrm{s}, 2,5 \mathrm{~m} / \mathrm{s}, 3 \mathrm{~m} / \mathrm{s}, 3.5 \mathrm{~m} / \mathrm{s}, 4 \mathrm{~m} / \mathrm{s}, 4.5$ $\mathrm{m} / \mathrm{s}, 5 \mathrm{~m} / \mathrm{s}$, and $5.5 \mathrm{~m} / \mathrm{s}$ can produce stable and laminar airflow.
\end{abstract}

\section{Keywords: Wind Tunnel, Wind Speed, Stability Test, Aerodynamic Flow}

\section{INTRODUCTION}

In the previous period, the research was done to test wind turbines, and fins with a wind tunnel could not be carried out on the FT Untirta campus because there was no aerodynamic test equipment or the force acting on an object hit the wind [4]. Therefore, a set of tools is needed to test aerodynamics, to study the effects of air passing through the solid object.

Wind tunnel (wind tunnel) is tube-structured test equipment in which air is forced to go fast, used to study the effects of aerodynamic flow on an object. The objector object being tested is placed in the middle of the test section/test area. Then the air is reacted through things with a fan scheme [1]. Therefore, in this study, an open system wind tunnel will be made which the manufacturing cost is lower than the closed system wind tunnel and can be easily maintained by laboratory students and is expected to have a maximum speed of $7 \mathrm{~m} / \mathrm{s}$, and has a test section size of $0.5 \mathrm{~m} \times 0.5 \mathrm{~m}$. Hence, the role of wind tunnels is significant in the New Renewable Energy Engineering laboratory.
Working principle in the open wind tunnel:

1. The electric motor is turned on and the fan blades connected to the electric motor will rotate and suck free air from the outside and enter through the contraction section [5].

2. Then the air flow which was initially turbulent after passing through the honeycomb and entering through one by one the honeycomb holes and the flow changed to laminar [5].

3. After that it enters the test section where the air flow changes rapidly due to after the contraction chamber [5].

4. Then enters the diffuser, and the air is released into the atmosphere [5]. 


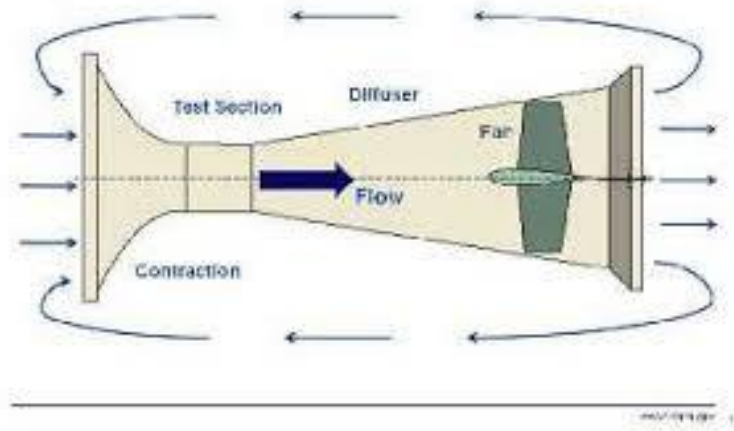

Figure 1. Open circuit wind tunnel

In general, the wind tunnel consists of:

1. The fan the main part of producing air.

2. Diffuser unction To restore static pressure to increase efficiency and shut off the flow circuit [6]. the length of the diffuser can be calculated based on the Eq., where $\mathrm{L}$ is the Length diffuser $\mathrm{m}$ ), is $\mathrm{R} 4$ radius outlet diffuser (m), R3 is radius inlet diffuser (m), and tilt angle diffuser $\left(^{\circ}\right)$

$$
L=\frac{R 4-R 3}{\tan \alpha}
$$

3. Test section is part of the wind tunnel to lay the model to be tested.

4. Contraction is a space with an area that is slowly shrinking, and small wind tunnels generally have a contraction ratio between 4 and 9 [7].

Inlet contraction $=$ (Contraction Rasio $\times$ Outlet Contraction)

Inlet Contraction $=\sqrt{\text { Inlet contraction }}$

5. Honeycomb serve to reduce flow turbulence. The length of the honeycomb should be between 6-8 times the cell size [7].

\section{METHODS}

In this study, the method used is the product de-sign method and has several stages in the research methodology, namely:

1. Determination of boundaries and definitions, the problem analysis step begins with identifying the need for a tool to test the aerodynamics of a model that deals directly with the wind in the new renewable energy engineering laboratory, Faculty of Engineering, Sultan Ageng Tirtayasa University.
2. Wind tunnel specification requirements, the test section of the wind tunnel has an area of $0,5 \mathrm{~m} \times 0,5 \mathrm{~m}$ and is expected to produce a wind speed of $7 \mathrm{~m} / \mathrm{s}$.

3. Determination of requirements list is shown in Table 1.

Table 1. Requirement List of Wind Tunnel

\begin{tabular}{|c|c|l|c|}
\hline No & Requirement & Description & $\begin{array}{c}\text { Demands } \\
\text { (D) or } \\
\text { Wishes } \\
\text { (W) }\end{array}$ \\
\hline 1 & Test Needs & $\begin{array}{l}\text { Able to test pro- } \\
\text { totype fin, tur- } \\
\text { bine and smoke } \\
\text { prototype, mod- } \\
\text { els. }\end{array}$ & D \\
\hline 2 & Dimen- & $\begin{array}{l}\text { Test Section } \\
\text { 1. Area 50 cm } \times \\
\text { so cm } \\
\text { 2. Length 80cm }\end{array}$ & D \\
\hline 3 & Wions & Rigid body & 1 \\
\hline 4 & Fan & $\begin{array}{l}\text { Easy to operate } \\
\text { Capable of suck- } \\
\text { ing air and pro- } \\
\text { ducing a wind } \\
\text { speed of 7 m/s in } \\
\text { the test section. }\end{array}$ & D \\
\hline
\end{tabular}

4. The material used, in terms of economic aspects and the presence of materials on the market, is Plywood with a thickness of $12 \mathrm{~mm}$ then the inner surface of the wind tunnel body is coated with vinyl or plastic stickers so that the wind tunnel surface becomes smooth.

5. Calculation Stage.

a) The calculation phase of the wind tunnel body parts.

b) The loss coefficient calculation phase refers to the surface roughness on each part of the wind tunnel to find the required fan power. For channel surface roughness, the material used is acrylic $(\varepsilon=0 \mathrm{~mm}),(\varepsilon / \mathrm{Dh})$ [3]. In other parts covered with vinyl, refer to the equivalent table Roughness for New Pipes [From Moody Ref. 7[8] and Colebrook Ref. 8[8] plastic surface roughness $=0.0($ smooth $)(\varepsilon=0 \mathrm{~mm}),(\varepsilon / \mathrm{Dh})$ [8].

c) In the drive systems, the rotation of the fan motor is $3000 \mathrm{rpm}$, then the power is channeled from the engine to the cutting wheel axle through a v-belt transmission with a ratio of 1 : 
2.6 so that it can transmit the fan rotation to $1150 \mathrm{rpm}$

\section{RESULTS AND DISCUSSION}

To obtain supporting data, the authors describe several stages or setups in the data collection process, namely:
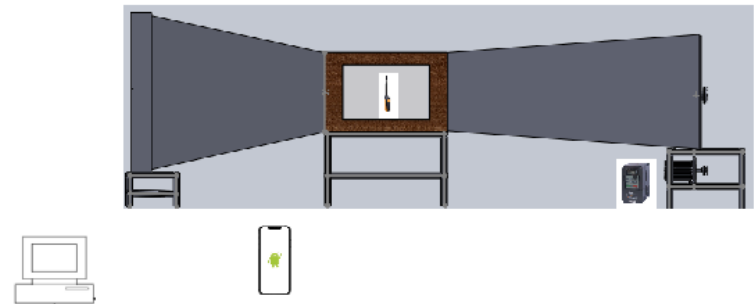

Figure 2 Experiment Setup

The following is an explanation of the data collection experiment according to the picture:

1. Number 1 in figure 2 is a position the testo $405 i$ in the test section, right in the middle of the space on the hotwire sensor, and activate the testo $405 \mathrm{i}$ and activate the connection.

2. Number 2 in Figure 2 is an activated the motor drive inverter and set the following speed variations.

Table 2. Wind Speed and Inverter Frequency

\begin{tabular}{|c|c|}
\hline Wind Speed & Inverter Frequency \\
\hline $0.5 \mathrm{~m} / \mathrm{s}$ & $5.60 \mathrm{~Hz}$ \\
\hline $1 \mathrm{~m} / \mathrm{s}$ & $8.43 \mathrm{~Hz}$ \\
\hline $1.5 \mathrm{~m} / \mathrm{s}$ & $11.54 \mathrm{~Hz}$ \\
\hline $2 \mathrm{~m} / \mathrm{s}$ & $15.55 \mathrm{~Hz}$ \\
\hline $2.5 \mathrm{~m} / \mathrm{s}$ & $19.10 \mathrm{~Hz}$ \\
\hline $3 \mathrm{~m} / \mathrm{s}$ & $23.55 \mathrm{~Hz}$ \\
\hline $3.5 \mathrm{~m} / \mathrm{s}$ & $27.20 \mathrm{~Hz}$ \\
\hline $4 \mathrm{~m} / \mathrm{s}$ & $31.57 \mathrm{~Hz}$ \\
\hline $4.5 \mathrm{~m} / \mathrm{s}$ & $35.65 \mathrm{~Hz}$ \\
\hline $5 \mathrm{~m} / \mathrm{s}$ & $41.20 \mathrm{~Hz}$ \\
\hline $5.5 \mathrm{~m} / \mathrm{s}$ & $45.03 z$ \\
\hline
\end{tabular}

3. Number 3 on the picture, when pressing the Run button on the inverter, the fan motor rotates drives the axial fan blades and sucks air.

4. Number 4 on the picture, then for the test, the wind speed is taken 3 data samples; for one data, the wind speed is tested with a duration of 1 minute. Then the testo $405 \mathrm{i}$ can read data every 2 seconds on the application of the intelligent probe. When the period has reached 1 minute, the data is downloaded in CSV or excel form

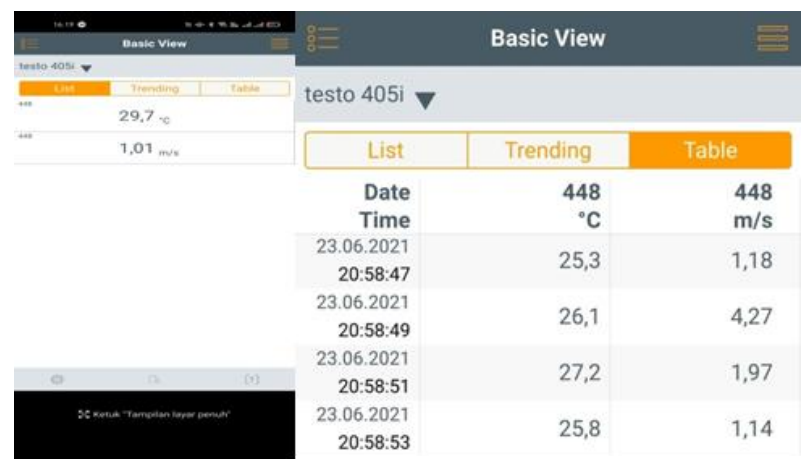

Figure 3 Application Testo 405i Smartprobes

5. Number 5 on the picture, then transfer data from smartphone to $\mathrm{PC} /$ laptop for later data processing and analysis.

6. The last one is data collection for rotation or rpm on the fan blades at each speed variation.

After the wind tunnel has been designed, calcu-lated and manufactured to the following specifications:

Table 3. Specification of Wind Tunnel

\begin{tabular}{|c|c|c|}
\hline \multicolumn{3}{|c|}{ Wind Tunnel Body } \\
\hline Part & Area & length \\
\hline Contraction & $1 \mathrm{~m} \times 1 \mathrm{~m}$ & $1.1 \mathrm{~m}$ \\
\hline Test Section & $0.5 \mathrm{~m} \times 0.5 \mathrm{~m}$ & $0.8 \mathrm{~m}$ \\
\hline Diffuser & $0.74 \mathrm{~m} \times 0.74 \mathrm{~m}$ & $1.6 \mathrm{~m}$ \\
\hline
\end{tabular}

Table 4. Table Drive System

\begin{tabular}{|c|c|}
\hline \multicolumn{2}{|c|}{ Drive System } \\
\hline Power & $400 \mathrm{Watt}$ \\
\hline $\mathrm{N}(\mathrm{rpm})$ & $1150 \mathrm{rpm}$ \\
\hline $\mathrm{V}$ & $380 \mathrm{~V}$ \\
\hline $\mathrm{T}(\mathrm{N} . \mathrm{m})$ & $3.478 \mathrm{Nm}$ \\
\hline
\end{tabular}

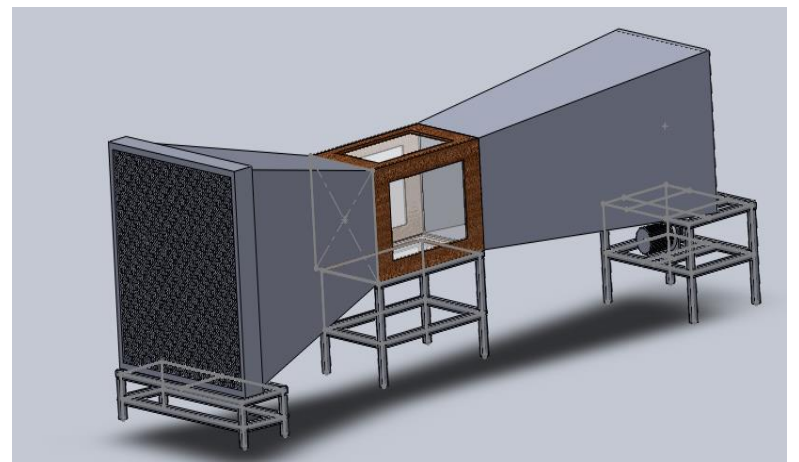




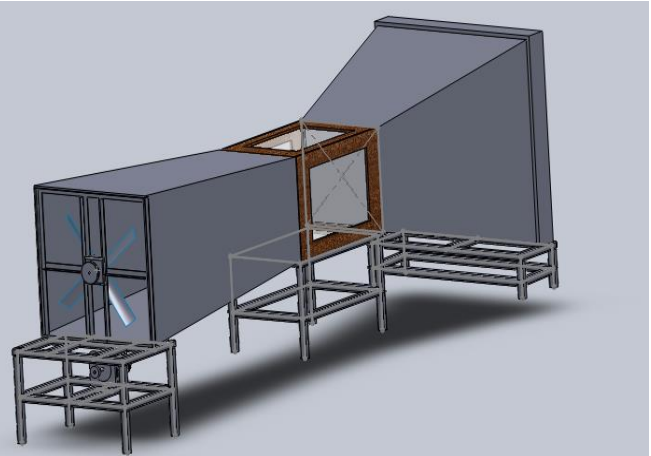

Figure 4 Picture of Design of Wind Tunnel with Test Section $0.5 \mathrm{~m} \times 0.5 \mathrm{~m}$

For comparison, based on simulations[6], to avoid turbulence due to edge currents, a square cross-section $(0.50 \times 0.50) \mathrm{m}$ in the variant 1 test section, section contraction cross-section measuring $(1.250 \times 1.250) \mathrm{m}$ [6]. The dimensions of the wind tunnel design this time have the same rectangular cross-sectional area $(0.50 \times$ $0.50) \mathrm{m}$ and a slightly different contraction section, namely $(1.0 \times 1.0) \mathrm{m}$, based on the simulation where the fan specifications are set to $8.75 \mathrm{~m} 3 / \mathrm{s}$, and has a wind speed of $9.713 \mathrm{~m} / \mathrm{s}$ on the test section and $6.664 \mathrm{~m} / \mathrm{s}$ on the contraction [6]. Then in the wind tunnel design with a test section $(0.50 \times 0.50) \mathrm{m}$, a fan with a specification of $3.70 \mathrm{~m} 3 / \mathrm{s}$ and gets a maximum speed of a test section of $5.5 \mathrm{~m} / \mathrm{s}$ is given.
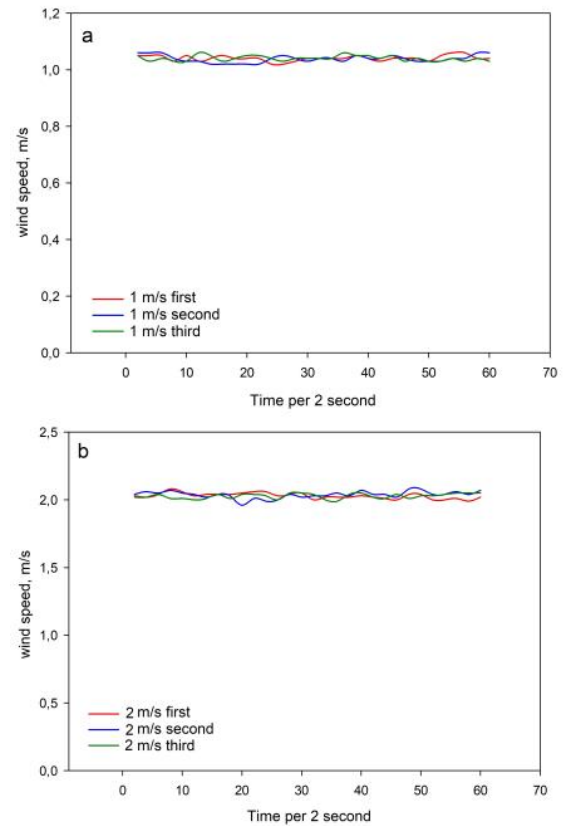
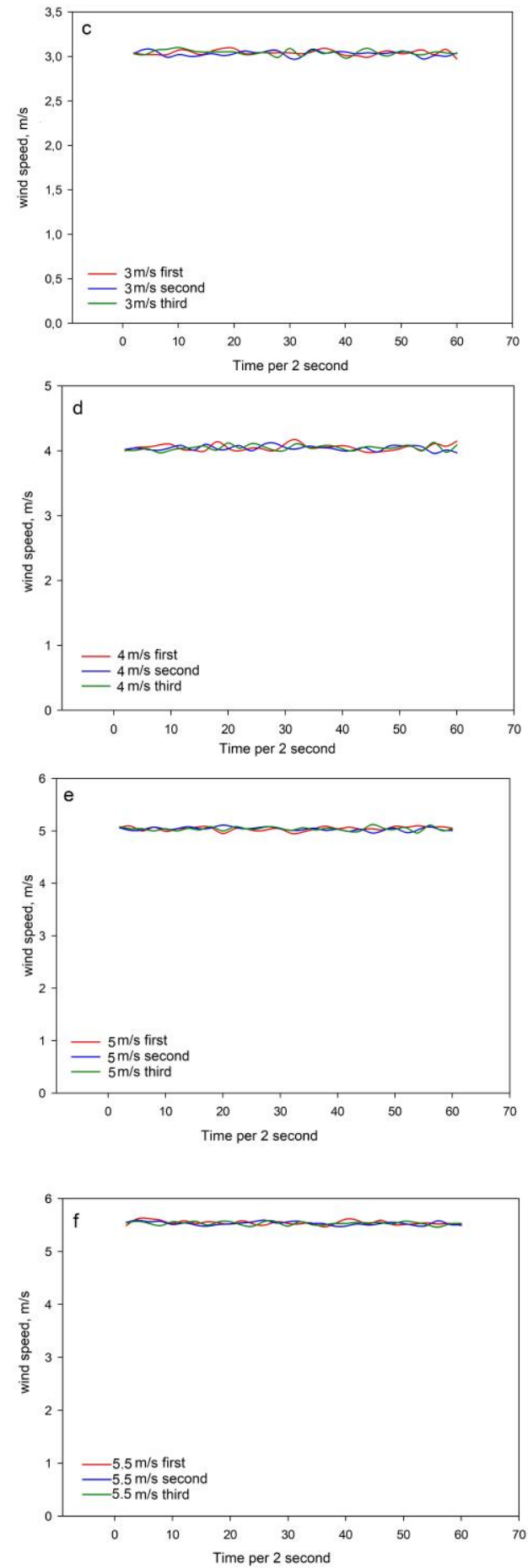

Figure 5 Wind speed chart of: $1 \mathrm{~m} / \mathrm{s}(\mathrm{a}) ; 2 \mathrm{~m} / \mathrm{s} \mathrm{(b)} ; 3 \mathrm{~m} / \mathrm{s}$ (c); $4 \mathrm{~m} / \mathrm{s}(\mathrm{d}) ; 5 \mathrm{~m} / \mathrm{s}(\mathrm{e}) ;$ and $5.5 \mathrm{~m} / \mathrm{s} \mathrm{(f)}$ 


\section{CONCLUSION}

From the design of a wind tunnel with a test section of $0.5 \mathrm{~m} \times 0.5 \mathrm{~m}$, it is obtained that this wind tunnel specification has a maximum wind speed of $5.5 \mathrm{~m} / \mathrm{s}$. After being tested and analysed, based on data and graphs, the wind tunnel can be used in the New Renewable Energy Engineering Laboratory and produces a stable airflow at various speeds of $1 \mathrm{~m} / \mathrm{s}, 2 \mathrm{~m} / \mathrm{s}, 3 \mathrm{~m} / \mathrm{s}, 4 \mathrm{~m} / \mathrm{s}, 5$ $\mathrm{m} / \mathrm{s}$, and $5.5 \mathrm{~m} / \mathrm{s}$ This wind tunnel uses a 400 -watt electric motor drive and a four-blade axial propeller with a diameter of $68 \mathrm{~cm}$.

\section{REFERENCES}

[1] A. T. G 2019 Analisis dan perhitungan pada daya motor untuk terowongan angin (wind tunnel) tipe subsonic dengan test section 0,2 x 0,2 m untuk alat peraga mekanika fluida skala labolatorium Mechonversio: Mechanical Engineering Journal 2 Nomor 2

[2] I. M. J. M. M. E. J. Idris 2019 Rancang bangun terowongan angin (wind tunnel) tipe subsonic dengan test section $0,2 \times 0,2 \mathrm{~m}$ untuk alat peraga mekanika fluida 2 no. 2 pp. 19-24

[3] C. Kusumohadi, N. Yoga, and H. Arrozi 2015 Perancangan awal terowongan angin kecepatan rendah untuk pengujian otomotif in SENS

[4] S. Garas 2019 Evaluasi Model Skala Kincir Angin Hybrid Vawt dan Pengujian Model Skalan di Terowongan Angin Cilegon Universitas Sultan Ageng Tirtayasa Cilegon

[5] Y. Ardiyani, C. E. Rustana, and R. J. W. F. Fahdiran 2018 Pengembangan desain terowongan angin sirkuit terbuka dengan tiga variasi panjang honeycomb menggunakan screenmesh 3 no. 1 pp. 93-101

[6] J. J. Ismail, Wina Libyawati, Damora Rhakasywi, Agri Suwandi, and P. A. Hendrayanto 2017 Optimization design of open circuit wind tunnel suction type International Journal of Mechanical \& Mechatronics Engineering IJMME-IJENS 17 No: 06

[7] S. U. J. P. P. I. Handayani 2014 Pengembangan dan analisa keseragaman aliran terowongan angin tipe terbuka sebagai sarana pengujian aerodinamika pp. A 309-A 314

[8] M. O. H. Rothmayer Fundamentals of fluid mechanics 7 th Ed. Munson 